\title{
Removal of Wet Deposited Phakopsora pachyrhizi Urediniospores from Soybean Leaves by Subsequent Rainfall
}

\author{
N. S. Dufault and S. A. Isard, Department of Plant Pathology, The Pennsylvania State University, University Park \\ 16802; and J. J. Marois, Department of Plant Pathology, and D. L. Wright, Department of Agronomy, University of \\ Florida - North Florida Research and Education Center, IFAS, Quincy 32351
}

\begin{abstract}
Dufault, N. S., Isard, S. A., Marois, J. J., and Wright, D. L. 2010. Removal of wet deposited Phakopsora pachyrhizi urediniospores from soybean leaves by subsequent rainfall. Plant Dis. 94:1336-1340.

Urediniospores of Phakopsora pachyrhizi, the soybean rust fungus, have a high probability of being removed from a soybean leaf by water runoff associated with subsequent rainfall after wet deposition. The effects of rainfall intensity, subsequent spore-free rainfall duration, and soybean leaf sample height on uredinia density were used to evaluate the retention of urediniospores on soybean leaf tissue. Rainfall simulations of 45 and $85 \mathrm{~mm} / \mathrm{h}$ were conducted on potted soybean plants that were inoculated with 2 min of urediniospore-injected simulated rainfall and exposed to 0,1 , and $30 \mathrm{~min}$ of subsequent spore-free rainfall. Urediniospore retention was estimated using uredinia density values obtained from a detached leaf bioassay for the sample heights of soil level, mid-canopy, and upper-canopy. Soil level leaflets inoculated with the $45 \mathrm{~mm} / \mathrm{h}$ rainfall intensity treatment had a higher $(P<0.01)$ mean number of uredinia $/ \mathrm{cm}^{2}$ than the $85 \mathrm{~mm} / \mathrm{h}$ treatment, even though they were inoculated with approximately $40 \%$ fewer urediniospores. Subsequent spore-free rainfall reduced $(P<0.01)$ uredinia density by as much as 38 and $91 \%$ for the 1- and 30-min durations, respectively. The relationship between uredinia density proportion and depth of rainfall was best fit using an inverse power empirical model. Our results indicate that a majority of the wet deposited $P$. pachyrhizi urediniospores would be removed from soybean leaf surfaces by subsequent rainfall, but sufficient percentages of spores (10 to 25\%) will likely remain on the leaf tissue long enough to germinate and infect during heavy summer rains lasting $\geq 30 \mathrm{~min}$.
\end{abstract}

Soybean rust, caused by Phakopsora pachyrhizi Sydow, is a devastating foliar pathogen of soybeans (Glycine max (L.) Merr.) that has caused significant yield losses in the southern United States $(27,39,46)$ and many other soybeanproducing regions throughout the world $(29,37,38,51)$. In North America, this pathogen overwinters on kudzu (Pueraria montana (Lour) Merr. var. lobata (Willd.) Maessen \& S. Almeida) in the Gulf Coast region of the United States and in Mexico $(10,26,42)$. Soybean rust is spread to major production regions of the central United States each year by the aerial transport of $P$. pachyrhizi urediniospores hundreds of kilometers from southern inoculum sources $(10,18,25,30)$. To date, this disease spread has occurred late in the growing season, and thus impact on soybean yield in the central United States has been minimal $(10,18)$. However, substantial yield reductions could occur if $P$. pachyrhizi urediniospores are deposited and able

Corresponding author: N. Dufault

E-mail: nsd114@psu.edu

Accepted for publication 13 July 2010.

doi:10.1094/PDIS-01-10-0068

(C) 2010 The American Phytopathological Society to initiate disease earlier in the growing season $(10,43)$.

Disease spread to distant host populations by a fungal plant pathogen is dependent upon viable propagules landing and remaining on their host's tissue long enough to germinate and infect (3). $P$. pachyrhizi urediniospores that are transported naturally through the atmosphere may be deposited onto host surfaces by the processes of gravitational settling, turbulence, and rainfall washout $(2,5$, 17,28,31). Rainfall washout has been indicated as the primary process involved in $P$. pachyrhizi urediniospore deposition within soybean-producing regions of the central United States $(5,24)$. This process is particularly important because large quantities of spores floating in an air layer extending many kilometers upward can be deposited onto soybean foliage in a wet and cloudy environment suitable for germination and infection. An estimated 2.5 to $4.0 \%$ of the viable urediniospores deposited into a soybean canopy by rainfall were deposited onto leaves in the lower canopy (12), where the first symptoms and signs are usually observed within a field $(10,40)$. However, much is still unknown about rainfall characteristics affecting the retention of urediniospores on soybean leaf tissue after a wet deposition event.
Important factors influencing the ability of fungal spores to remain on a leaf surface long enough to infect include physical characteristics of both the leaf (i.e., leaf trichomes and veins) and spore (i.e., size and appendages) as well as possible interactions of spore adhesive material with the plant (1). Adhesion of $P$. pachyrhizi urediniospores to soybean leaf surfaces was correlated to germination, and the germination/adhesion process was observed to begin as early as $30 \mathrm{~min}$ after deposition under ideal environmental conditions (49). Considering that a majority of the fungal spores are removed from the atmosphere early $(<20 \mathrm{~min})$ in a heavy rainfall event $(4,8,17,31,45)$, it follows that a large portion of the urediniospores deposited by rainfall will be exposed to additional precipitation before they germinate and adhere to the soybean leaf. Thus, there is a high probability that wet deposited $P$. pachyrhizi urediniospores will be removed from a leaf surface by rainfall and/or water runoff associated with subsequent precipitation $(9,16,31)$.

In this study, it was hypothesized that exposure of urediniospores to subsequent spore-free rainfall after wet deposition will result in fewer urediniospores being retained by the soybean leaf surface. A rainfall simulator was used to examine the retention of $P$. pachyrhizi urediniospores on soybean leaf tissue following an inoculation with simulated rainfall. The objectives of this research were to (i) ascertain if wet deposited urediniospores can be removed from the soybean leaf tissue by subsequent rainfall, and (ii) examine the effects of rainfall duration and intensity on urediniospore removal rates.

\section{MATERIALS AND METHODS}

Soybean preparation. Pots of the determinate, medium height soybean cultivar DP7220RR (Delta \& Pine Land, Monsanto Co.) were planted on multiple occasions between days of the year 81 and 110 in 2007 using Miracle-Gro Enriched Potting Mix (Miracle-Gro Lawn Products; $\mathrm{N}_{2} \mathrm{H}_{3}-$ $\left.\mathrm{P}_{2} \mathrm{O}_{5}-\mathrm{K}_{2} \mathrm{O}: 0.21-0.07-0.14\right)$ at the University of Florida, North Florida Research and Education Center (NFREC) in Quincy. The soybean plants were cultivated during a time of year when soybean rust had not been observed in Gadsden County, FL, and were kept in a soybean rust free greenhouse that was visually inspected each day for 
disease. The DP7220RR cultivar was used because it had growth and development traits that were recommended for soybean production within the Quincy region (50). Plants were watered daily and fertilized once each month with $5 \mathrm{ml}$ of Osmocote Outdoor \& Indoor Release Plant Food (The Scott's Company; $\mathrm{N}_{-} \mathrm{P}_{2} \mathrm{O}_{5}-\mathrm{K}_{2} \mathrm{O}$ : 19-6-12) until they were at soybean growth stages $\mathrm{R} 2$ to R3 (13) and at heights of 28 to $35 \mathrm{~cm}$.

Inoculum production and preparation. Soybean plants were mist inoculated with $P$. pachyrhizi urediniospores (23) collected from multiple kudzu patches in the Florida counties of Gadsden and Duval, and cultivated in a NFREC greenhouse with relative humidity $>90 \%$. Urediniospores were vacuumed from sporulating lesions with a large single cyclone spore collector (G-R Manufacturing Co.) and gathered into $20-\mathrm{ml}$ glass vials. The urediniospores were then separated into $0.04-\mathrm{g}$ cohorts and stored in 1.5-ml Eppendorf tubes at $24^{\circ} \mathrm{C}$ for less than $30 \mathrm{~h}$ before use in the rainfall simulations.

Inoculum suspensions used in the rainfall simulations were mixed $1 \mathrm{~min}$ before each run to avoid possible urediniospore germination. The inoculum suspensions consisted of a 0.04-g urediniospore cohort and $500 \mathrm{ml}$ of deionized water that was agitated in a 2-liter plastic bottle for $1 \mathrm{~min}$. A $20-\mathrm{ml}$ sample of the 500-ml urediniospore suspension was collected on ice to estimate viability and concentration. Urediniospore concentrations were calculated using a hemacytometer with mean urediniospore concentrations of 4,000 and 6,000 spores $/ \mathrm{ml}$ for the 45 and $85 \mathrm{~mm} / \mathrm{h}$ treatments, respectively. The differences in urediniospore concentrations can be attributed to variation and error associated with weight measurements and hemacytometer counts. The spore germination proportion was determined by pipetting $1 \mathrm{ml}$ of the spore suspension onto each of two $100 \times$ $15 \mathrm{~mm}$ plastic petri plates containing 10 $\mathrm{g} /$ liter water agar (Difco Bacto). These plates were incubated in complete darkness for $16 \mathrm{~h}$ at $24^{\circ} \mathrm{C}\left( \pm 5^{\circ} \mathrm{C}\right)(23)$. The proportion of urediniospores that germinated was obtained from the first 100 urediniospores observed when examined at $\times 200$ within each of the two plates. The mean proportion of urediniospores that germinated was 0.53 (range: 0.33 to 0.92 ) when averaged across treatments and repetitions.

Rainfall simulation and assessment. Rainfall simulation experiments were conducted within a large enclosed building at the NFREC during the months of April and May 2007. In this study, a portable plot rainfall simulator designed specifically for fungal spore wet deposition was used to generate simulated rains of 45 and 85 $\mathrm{mm} / \mathrm{h}$ over a $2 \times 2 \mathrm{~m}$ sample area (11). These rainfall rates are commonly observed for short periods in warm weather rainstorms of Illinois $(19,20)$ and throughout the rest of the United States (6). Rain- drop sizes ranged from 0.2 to $3.3 \mathrm{~mm}$ with median drop diameters of 1.0 and $1.6 \mathrm{~mm}$ for the 45 and $85 \mathrm{~mm} / \mathrm{h}$ treatments, respectively. The water used to generate rainfall in these experiments was from an unfiltered well located near the enclosed building.

For each experimental repetition, individually potted soybean plants were inoculated for 2 min with urediniospore injected rainfall and exposed to subsequent rainfall durations of 0,1 , and $30 \mathrm{~min}$ without spores at 45 and $85 \mathrm{~mm} / \mathrm{h}$ rainfall intensities. Before each rainfall intensity treatment simulation, 12 potted soybean plants were placed uniformly within the simulator's sample area. Then each of the three subsequent rainfall duration treatments was randomly assigned to 4 of the 12 plants within that sample area. After assigning the treatments, urediniospore suspensions were mixed and all 12 soybean plants were exposed to 2 min of simulated rainfall with urediniospores. Immediately following the inoculation, the 0 min plants were removed and leaves were sampled for the bioassay. The remaining plants were then exposed to subsequent rainfall durations of 1 and $30 \mathrm{~min}$ without urediniospores, with four plants being removed and sampled immediately after the 1-min period and the final four plants being exposed to $29 \mathrm{~min}$ more of simulated sporefree rainfall. These experimental repetitions were repeated three times on the days of the year 103, 134, and 137.

Soybean plant height (ht), from the soil to the top leaf node, was measured before each rainfall simulation with the mean plant heights of $28 \mathrm{~cm}$ (range: 23 to 36 ) and $35 \mathrm{~cm}$ (range: 31 to 41 ) being recorded for the rainfall intensity treatments of 45 and $85 \mathrm{~mm} / \mathrm{h}$, respectively. Immediately after exposure to each subsequent rainfall duration treatment, the middle leaflet of a designated trifoliolate was harvested from each plant at the heights of soil level (0), mid-canopy $(0.5 \mathrm{ht})$, and upper-canopy $(1.0 \mathrm{ht})$. For the sample leaflet at soil level, a detached, "rust free" leaflet was placed on the soil surface of the pot 2 min before exposure to simulated rainfall treatments. Leaflets were placed adaxial side up on the soil surface to estimate the number of spores that penetrated through the canopy of the potted plants. Thus, a total of four leaflets were subsampled for each of the 18 treatment combinations, giving a total sample of 72 soybean leaflets per experimental repetition.

The detached soybean leaflet samples were transferred to $100 \times 15 \mathrm{~mm}$ plastic petri plates containing $10 \mathrm{~g} /$ liter water agar (Difco Bacto) within 5 min of exposure to each rainfall treatment and incubated on a lab bench with 12 to $14 \mathrm{~h}$ of natural sunlight ( $\max$ solar radiation intensity $\sim 45$ $\left.\mathrm{W} / \mathrm{m}^{2}\right)$ at $24^{\circ} \mathrm{C}\left( \pm 5^{\circ} \mathrm{C}\right)$ for 14 days $(7,48)$. The uredinia density of soybean rust on the leaves was evaluated using a microscope at $\times 100$ to count the number of uredinia per leaf. The area $\left(\mathrm{cm}^{2}\right)$ of each leaf was measured using a LI-3000 Portable Area Meter (LI-COR Environmental). The number of uredinia per $\mathrm{cm}^{2}$ was calculated for each sample and used to estimate the soybean leaf viable urediniospore density (D) by dividing the number of uredinia per soybean leaf by its recorded leaf area.

Data analysis. Urediniospore density (uredinia/ $/ \mathrm{cm}^{2}$ ) for leaves exposed to 1 or 30 min of subsequent rainfall $\left(\mathrm{D}_{\mathrm{P}}\right)$ was divided by the mean uredinia density of the leaves not exposed to subsequent rainfall $\left(\mathrm{D}_{\mathrm{C}}\right)$, and this proportion was subtracted from 1 to obtain the proportion of urediniospores removed by the simulated rainfall event $\left(S_{R}\right.$ $\left.=1-\left(\mathrm{D}_{\mathrm{P}} / \mathrm{D}_{\mathrm{C}}\right)\right)(21,35,41)$. Following Madden et al. (35) and Ntahimpera et al. (41), an exponential decline trend was assumed for the rate of urediniospore removal and calculated by: $B_{R}=\left[\ln \left(D_{C}\right)-\ln \left(D_{P}\right)\right] / T$, where $T$ (min) is the duration of the subsequent rainfall event.

All data analysis was completed using SAS version 9.1 (SAS Institute, Cary, NC) with comparisons considered statistically significant at $\alpha=0.05$. The experimental design was a split-split plot with rainfall intensity as the main plot, rainfall duration the split plot, and plant height the splitsplit plot. All effects on urediniospore density (D), proportion of spores removed $\left(S_{R}\right)$, and rate of spore removal $\left(B_{R}\right)$ were tested in an analysis of variance with the appropriate error terms obtained using the MIXED procedure of SAS (32). Repetitions were considered to be random effects. Linear least squares regression analysis was conducted using PROC REG statement to evaluate the relationship between uredinia density proportion with depth of subsequent rainfall. The uredinia density proportions were calculated by normalizing the $\mathrm{D}_{\mathrm{P}}$ values from 1 and 30 min of subsequent rainfall with the corresponding $\mathrm{D}_{\mathrm{C}}$ value. The depth of subsequent rainfall was calculated by multiplying the rainfall intensity $(45$ or $85 \mathrm{~mm} / \mathrm{h}$ ) by the duration of the subsequent rainfall ( 0.02 or $0.50 \mathrm{~h}$ ). These data were quantified using the negative exponential $\left(Y=a e^{(-b X)}\right)$ and inverse power $\left(Y=a X^{-b}\right)$ empirical models which were analyzed using linear transformations. In both models, $Y$ is the uredinia density for a given subsequent rainfall depth, $X(\mathrm{~mm})$. Both $a$ and $b$ are estimated model parameters, and $e$ is the napierian base. An $F$ test was conducted using PROC GLM in SAS to compare regression coefficients from the three sample height groups for each relationship. Since some of the proportions had data points of 0 , a value of 0.1 was added to all of them before they were transformed for each model.

\section{RESULTS}

Analysis of variance (ANOVA) indicated that significant interaction effects on uredinia density were present between sample height and rainfall intensity, as 
well as sample height and subsequent rainfall treatments. Soybean leaves in the 85 $\mathrm{mm} / \mathrm{h}$ treatment on average were exposed to 1.5 times as many viable $P$. pachyrhizi urediniospores during the 2-min rainfall inoculation period compared to those in the $45 \mathrm{~mm} / \mathrm{h}$ treatment. Yet, a higher mean number of uredinia $/ \mathrm{cm}^{2}$ (1.05) was observed on soil level leaflet samples exposed to the low rainfall intensity treatment than the mean number (0.36) observed for the high rainfall intensity treatment (Fig. 1). However, no differences in the mean number of uredinia/ $/ \mathrm{cm}^{2}$ were observed between the mid-canopy and upper-canopy samples for the 45 and 85 $\mathrm{mm} / \mathrm{h}$ rainfall intensity treatments (Fig. 1). Higher mean uredinia densities were recorded on soil level leaflet samples exposed to 0 (1.02) and 1 (0.93) min of subsequent rainfall compared to all other sample height and subsequent rainfall treatment combinations (Fig. 2).

Only the duration of subsequent sporefree rainfall was indicated by ANOVA to have a significant effect on the proportion of spores removed $\left(S_{R}\right)$. A higher mean $S_{R}$ was calculated for leaflets from treatments exposed to $30 \mathrm{~min}$ of subsequent spore-free rainfall compared to the $1 \mathrm{~min}$ treatment

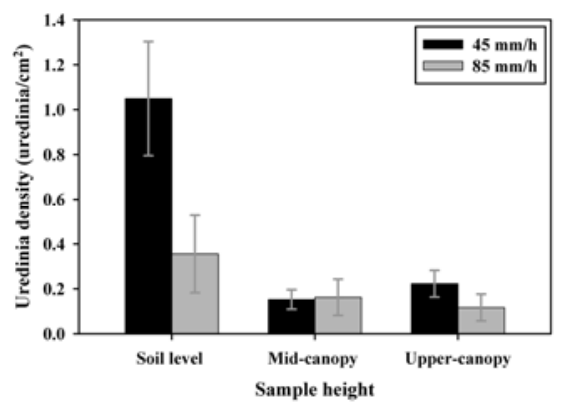

Fig. 1. Mean uredinia density ( \pm standard error) plotted against the sample height treatments at which soybean leaf tissue was harvested for each of the two rainfall intensities. Soybean plants were exposed to $2 \mathrm{~min}$ of rainfall with urediniospores and then to subsequent rainfall durations of 0,1 , and $30 \mathrm{~min}$ without spores at rainfall intensities of 45 and $85 \mathrm{~mm} / \mathrm{h}$.

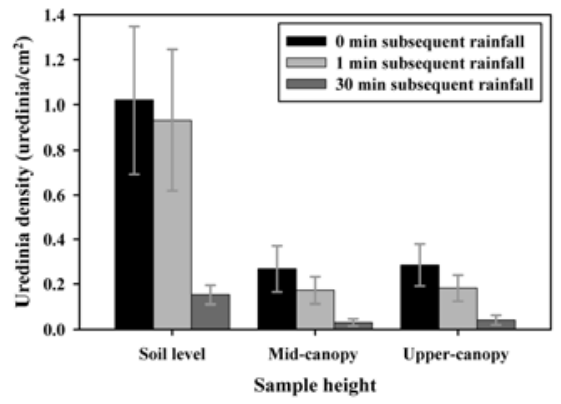

Fig. 2. Mean uredinia density ( \pm standard error) plotted against the sample height treatments at which soybean leaf tissue was harvested for each of the three subsequent spore-free rainfall durations. Soybean plants were inoculated with 2 min of urediniospore injected rainfall at intensities of 45 and $85 \mathrm{~mm} / \mathrm{h}$.
(Table 1). The proportion of urediniospores removed by the rainfall intensities of 45 and $85 \mathrm{~mm} / \mathrm{h}$ were as high as 90 and $91 \%$ within the first $30 \mathrm{~min}$ of spore-free rainfall after a 2-min rainfall inoculation period (Table 1). No treatment effects were observed on the rate of spore removal $\left(B_{R}\right)$; however, a lower mean $B_{R}$ was calculated for the 30-min subsequent duration compared to the 1-min duration (Table 1). This effect of subsequent rainfall on $B_{R}$ was nearly significant, with an ANOVA $P$ value of 0.067 .

Initially, the regression curve of the uredinia density proportion decreased rapidly with depth of subsequent spore-free rainfall and then at a reduced rate for depths of $5 \mathrm{~mm}$ or greater (Fig. 3). This relationship was better fit using the inverse power than the negative exponential empirical model based on the higher $R^{2}$ values observed for that model (Table 2). Differences among the inverse power model regression coefficients for each sample height treatment were not significant $(F=1.08, P$ $=0.352$ ), and therefore the data from all sample heights were pooled to estimate a single regression function (Fig. 3).

\section{DISCUSSION}

The removal of fungal spores from their deposition substrate by rain is an important process in long distance disease spread. The urediniospores of $P$. pachyrhizi have been observed to adhere to soybean leaves as early as $30 \mathrm{~min}$ under ideal environmental conditions (49). Thus, viable urediniospores deposited during long distance transport events will most likely be exposed to considerable periods of subsequent rainfall before they adhere and infect host plants. This study demonstrates the importance of rainfall duration and intensity in determining the proportion of $P$. pachyrhizi urediniospores that are retained on soybean leaves after wet deposition.
Subsequent spore-free rainfall durations of 1 and $30 \mathrm{~min}$ were observed to reduce uredinia density on soybean leaves by as much as 38 and $91 \%$, respectively. The proportion of urediniospores removed during the 30-min spore-free subsequent rainfall treatment are similar to those reported in other studies examining the effects of rainfall wash-off on spore removal from strawberry fruits (50 to 90\%) $(34,35,41)$, the depletion of a fungal biological control agent from potato leaf surfaces (89 to 95\%) (21), and the removal of brown and yellow rust spores from source plants (89 to $98 \%$ ) (14). Although a majority of the wet deposited $P$. pachyrhizi urediniospores could be removed from soybean leaf surfaces by subsequent spore-free rainfall, our results indicate that 10 to $25 \%$ of the P. pachyrhizi urediniospores deposited by a summer rainfall lasting $\geq 30 \mathrm{~min}$ would be expected to remain in contact with the soybean leaf surface long enough to begin the germination/adhesion process.

Studies examining the use of biological control agents on leaf tissue $(21,22)$ and plant pathogen dispersal $(33,35,41,44)$ have suggested that rainfall intensity is a key variable in determining the number of spores retained on plant tissues. In this study, however, rainfall intensity was not indicated as an important factor in the removal of $P$. pachyrhizi urediniospores from soybean leaves by subsequent sporefree rainfall. One reason for this apparent discrepancy could be differences in inoculation methods. Previous studies have artificially applied known quantities of spores to plant tissue, but in our experiments urediniospores were inoculated onto soybean leaves through simulated rainfall. With our inoculation method, the simulated rainfall that is depositing urediniospores onto soybean leaves is also initiating runoff that can remove them.

Table 1. The effects of rainfall intensity, leaflet height and subsequent rainfall duration on the removal of urediniospores from soybean leaf tissue

\begin{tabular}{|c|c|c|c|c|c|}
\hline \multirow[b]{2}{*}{$\mathbf{R I}(\mathbf{m m} / \mathbf{h})^{\mathbf{a}}$} & \multirow[b]{2}{*}{ Leaf height $^{\text {b }}$} & \multicolumn{2}{|c|}{$\begin{array}{c}\text { Spore removal proportion } \\
\left(\mathbf{S}_{\mathbf{R}}\right)^{\mathbf{d}}\end{array}$} & \multicolumn{2}{|c|}{$\begin{array}{c}\text { Spore removal rate } \\
\left(\mathbf{B}_{\mathrm{R}} ; \mathbf{m i n}^{-1}\right)^{\mathrm{e}}\end{array}$} \\
\hline & & $1 \min ^{c}$ & $30 \mathrm{~min}$ & $1 \mathrm{~min}$ & $30 \mathrm{~min}$ \\
\hline \multirow[t]{3}{*}{45} & Soil level & 0.15 & 0.86 & 0.17 & 0.07 \\
\hline & Mid-canopy & 0.38 & 0.90 & 0.58 & 0.08 \\
\hline & Upper-canopy & 0.37 & 0.73 & 0.54 & 0.06 \\
\hline \multirow[t]{4}{*}{85} & Soil level & 0.02 & 0.75 & 0.02 & 0.06 \\
\hline & Mid-canopy & 0.15 & 0.91 & 0.18 & 0.08 \\
\hline & Upper-canopy & 0.31 & 0.75 & 0.46 & 0.03 \\
\hline & Duration mean & 0.23 & 0.82 & 0.33 & 0.06 \\
\hline
\end{tabular}

${ }^{a}$ Rainfall intensity (RI) match of the rainfall simulator's droplet distributions with natural rainfall events.

${ }^{\mathrm{b}}$ Leaf sampling heights of soil level, mid-canopy $(0.5 \mathrm{ht})$, and upper-canopy $(1 \mathrm{ht})$ where ht is the soybean plant's height.

${ }^{c}$ Duration of subsequent rainfall without spores.

${ }^{d} S_{R}$ is derived from the function: $1-\left(D_{P} / D_{C}\right)$ in which $D_{P}$ is the urediniospore density after exposure to subsequent rainfall of either 1 or $30 \mathrm{~min}$, and $\mathrm{D}_{\mathrm{C}}$ is the urediniospore density before exposure to subsequent rainfall ( $0 \mathrm{~min}$ control leaves). D values were estimated from recorded uredinia density data. Significantly higher uredinia proportions were observed in the 30 min duration compared to the 1 min duration.

${ }^{e} B_{R}$ was derived from the function: $\left[\ln \left(D_{C}\right)-\ln \left(D_{P}\right)\right] / T$ in which $D_{P}$ and $D_{C}$ are urediniospore density values described for $S_{R}$ and $T$ is the duration of subsequent rainfall in minutes. No significant differences were noted between the duration treatments. 
Furthermore, our results indicate that most of the urediniospores deposited during the rainfall simulations were not retained by the single plant canopies. Greater quantities of urediniospores were retained on the leaflets placed at soil level than on the other sample height treatments, especially early in the simulated rain event. It was also observed that soil level leaflets exposed to the low intensity rainfalls had higher uredinia densities than those exposed to the high intensity rainfalls. These results indicate that early in a rain event, when a majority of the spores are washed from the atmosphere $(17,31)$, higher rainfall intensities will result in lower initial retention of $P$. pachyrhizi urediniospores on soybean leaves compared to lower rainfall intensities when inoculum levels are high. However, this effect will likely no longer be apparent after subsequent sporefree rainfall durations of $30 \mathrm{~min}$ or more.

The information gathered in this study can be used to estimate urediniospore wet deposition and retention after a long distance dispersal event. For example, during 21 to 28 August 2007, a strong low pressure system became established over the Great Lakes with intense winds blowing from Texas and Oklahoma toward the central United States. At this time, soybean rust epidemics were present in many commercial fields in Texas and Louisiana, and the pathogen had been identified in sentinel plots as far north as Oklahoma and Arkansas. Rainwater spore trap network records obtained from the ipmPIPE website (25) for the corresponding week indicate that $P$. pachyrhizi urediniospores were collected from two locations in Iowa, two in Illinois, two in Kentucky, and one in southwest Indiana. A location in northeastern Iowa received $55.1 \mathrm{~mm}$ of rain, and the urediniospore density for the collection estimated by qPCR assays was 243 urediniospores $/ \mathrm{m}^{2}$ (47). The ipmPIPE website indicates that symptoms of soybean rust began to be identified in fields within a broad belt stretching from western Iowa to southwestern Ontario approximately 31 days later. Assuming that 2 to $3 \%$ of the urediniospores washed out of the air during this rainfall event were deposited on foliage within the low and mid-sections of a nearby soybean canopy (12), and that about $10 \%$ of these urediniospores were retained on the leaves after the ensuing heavy rainfall (Fig 3), the deposition density of spores with the potential to infect soybean plants would have been roughly $0.6 \mathrm{spore} / \mathrm{m}^{2}$. Assuming that nearby soybean fields were planted at a density of 300,000 to 400,000 seeds/ha and had 9 to 12 green leaves (3 to 4 trifoliolates) remaining in the low and mid-canopy sections at the end of August, that the deposited $P$. pachyrhizi urediniospores were viable, and environmental conditions were conducive for infection, one would expect to find approximately 1 uredinia per 450 to
800 leaves in the first generation of infection. This density is likely an overestimation because the urediniospores in the rainwater collectors must have been exposed to ultraviolet radiation during their long distance transport, and thus a large proportion would likely not have been viable by the time they were deposited (23).

$P$. pachyrhizi uredinia develop and sporulate in vitro as early as 9 days after the inoculation of soybean leaf tissue with urediniospores (36). Thus, it is likely that second or third generation uredinia were present when soybean rust was initially detected in Iowa approximately 1 month (31 days) after the aforementioned deposition event. The current protocol used for soybean rust scouting in sentinel plots and commercial fields calls for sampling and examining 100 soybean leaves from the lower and middle canopy sections (15). Our results and subsequent calculations suggest that after a heavy $P$. pachyrhizi urediniospore deposition event, such as that experi- enced in Iowa during late August 2007, one should expect $\leq 1$ uredinia to develop per 450 to 800 leaves. It follows that the current sampling protocol for soybean rust is more likely to detect uredinia from the second or third generation than from the first generation when employed at locations far from known sources of inoculum.

This study establishes the relationship between rainfall characteristics and the proportion of urediniospores retained on soybean leaves after wet deposition. Spore removal from soybean leaves was examined using canopies composed of potted plants in a rainfall simulator, and thus our findings only provide a first approximation of the relationships between the factors that control wash-off of spores from leaves in field situations where the soybean canopy is closed and splash dispersal of spores may be important. In addition to providing a further understanding of the urediniospore wet deposition process, this research also supplies important quantita-

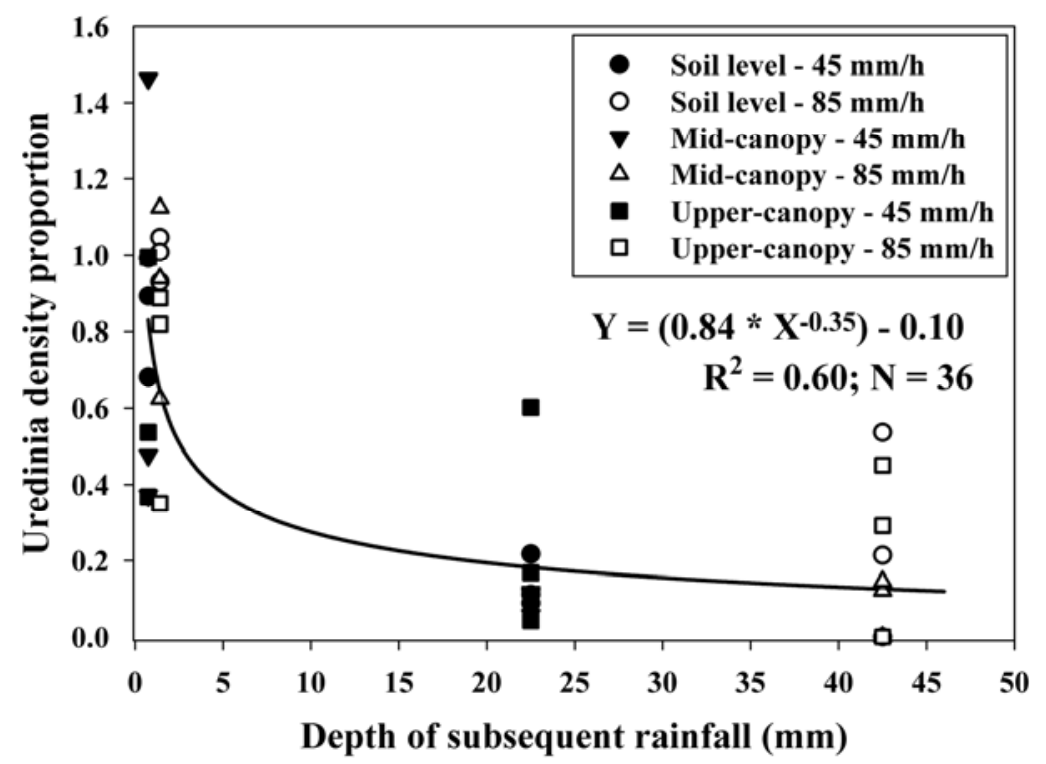

Fig. 3. Relationship between depth of subsequent rain without Phakopsora pachyrhizi urediniospores and uredinia density proportion. The uredinia density proportion was calculated by normalizing soybean leaf severity values from 1 and $30 \mathrm{~min}$ of subsequent rainfall with the corresponding severity values recorded from leaves not exposed to subsequent rainfall. All leaves were inoculated by $2 \mathrm{~min}$ of rainfall with spores. Soil level, mid-canopy $(0.5 \mathrm{ht})$, and upper-canopy $(1.0 \mathrm{ht})$ were heights where soybean leaf tissue was harvested, and ht is average plant height. Rainfall intensities for the simulations were 45 and $85 \mathrm{~mm} / \mathrm{h}$. The trend line was calculated using an inverse power empirical model $\left(Y=a X^{-b}\right)$ in SAS with the PROC REG statement.

Table 2. Coefficients for nonlinear relationships of soybean rust uredinia density proportion ${ }^{\mathrm{a}}$ with depth of subsequent rain

\begin{tabular}{lcccccccc}
\hline & \multicolumn{3}{c}{ Inverse power $^{\mathbf{b}}$} & & \multicolumn{3}{c}{ Exponentialc $^{\mathbf{c}}$} \\
\cline { 2 - 4 } \cline { 6 - 8 } Sample height $^{\mathbf{d}}$ & $\boldsymbol{a}$ & $\boldsymbol{b}$ & $\boldsymbol{R}^{\mathbf{2}}$ & & $\boldsymbol{a}$ & $\boldsymbol{b}$ & $\boldsymbol{R}^{\mathbf{2}}$ \\
\hline Soil level & 0.99 & -0.39 & 0.69 & & 0.92 & -0.04 & 0.58 \\
Mid-canopy & 0.84 & -0.43 & 0.77 & & 0.80 & -0.04 & 0.70 \\
Upper-canopy & 0.71 & -0.26 & 0.39 & & 0.69 & -0.03 & 0.35 \\
\hline
\end{tabular}

a The uredinia density proportions were calculated by normalizing soybean leaf uredinia density values from 1 and 30 min of subsequent rainfall with the corresponding uredinia density values recorded for leaves not exposed to subsequent rainfall.

b The inverse power empirical model, $Y=a X^{-b}$.

c The negative exponential model empirical model, $Y=a e^{(-b X)}$.

d Soybean leaf samples were collected at the heights of soil level, mid-canopy ( $0.5 \mathrm{ht})$, and uppercanopy (1 ht), where ht is the soybean plant's height. 
tive relationships for improved parameterization of the Integrated Aerobiology Modeling System that is currently run on a daily basis to inform stakeholders in the central United States of the risk of soybean rust spread (24). Finally, this study provides important insight about when current protocols used for soybean rust scouting are likely to detect disease after a long distance transport event.

\section{ACKNOWLEDGMENTS}

This research was funded by grants from the USDA Cooperative States Research, Education and Extension Service National Research Initiative Animal and Plant Biosecurity grant program and the Pennsylvania State University. We thank Dario Narvaez and all the staff at the NFREC for their assistance with these experiments. We would also like to express our gratitude to Glen Hartman and his staff at the University of Illinois for their support and help. A special thanks to Timothy Grove and Justin Dillon for their valuable input into and assistance with these experiments.

\section{LITERATURE CITED}

1. Allen, E. A., Hoch, H. C., Steadman, J. R., and Stavely, R. J. 1991. Influence of leaf surface features on spore deposition and the epiphytic growth of phytopathogenic fungi. Pages 87-110 in: Microbial Ecology of Leaves. J. H. Andrews and S. S. Hirano, eds. Springer, New York.

2. Andrade, D., Pan, Z., Dannevik, W., and Zidek, J. 2009. Modeling soybean rust spore escape from infected canopies: Model description and preliminary results. J. Appl. Meteor. Climatol. 48:789-803.

3. Aylor, D. E. 1986. A framework for examining inter-regional aerial transport of fungal spores. Agric. For. Meteorol. 38:263-288.

4. Aylor, D. E., and Sutton, T. B. 1992. Release of Venturia inaequalis ascospores during unsteady rain: Relationship to spore transport and deposition. Phytopathology 82:532-540.

5. Barnes, C. W., Szabo, L. J., and Bowersox, V. C. 2009. Identifying and quantifying Phakopsora pachyrhizi spores in rain. Phytopathology 99:328-338.

6. Bodtmann, W. F., and Ruthroff, C. L. 1976. The measurement of $1 \mathrm{~min}$ rain rates from weighing raingage recordings. J. Appl. Meteorol. 15:1160-1166.

7. Burdon, J. J., and Marshall, D. R. 1981. Evaluation of Australian native species of Glycines for resistance to soybean rust. Plant Dis. 65:44-45.

8. Chamberlain, A. C. 1967. Deposition of particles to natural surfaces. Pages 138-164 in: Airborne Microbes: Symposium of the Society for General Microbiology. P. H. Gregory and J. L. Monteith, eds. Cambridge University Press, Cambridge.

9. Cook, M. 1980. Host-parasite relations in uredial infections of peanut by Puccinia arachidis. Phytopathology 70:822-826.

10. Dorrance, A. E., Draper, M. A., and Hershman, D. E., eds. 2008. Using foliar fungicides to manage soybean rust. Land-Grand Universities Cooperation NCERA-208 and OMAF, Bull. SR-2008.

11. Dufault, N. S., and Isard, S. A. 2010. A portable rainfall simulator for evaluating the wet deposition of plant pathogens. Appl. Eng. Agric. 26:71-78.

12. Dufault, N. S., Isard, S. A., Marois, J. J., and Wright, D. L. 2010. The influence of rainfall intensity and soybean plant row spacing on the vertical distribution of wet deposited Phakopsora pachyrhizi urediniospores. Can. J. Plant Pathol. 32:162-169.

13. Fehr, W. R., and Caviness, C. E. 1977. Stages of soybean development. Spec. Rep. 80. Iowa State Univ. Coop. Ext. Serv., Ames.
14. Geagea, L., Huber, L., Sache, I., Flura, D., McCartney, H. A., and Fitt, B. D. L. 2000. Influence of simulated rain on dispersal of rust spores from infected wheat seedlings. Agric. For. Meteorol. 101:53-66.

15. Giesler, L. J., and Hershman, D. E. 2007. Overview of value of sentinel plots for 2007. Proc. 2007 Nat. Soybean Rust Sympos.

16. Gregory, P. H. 1970. The leaf as a spore trap. Pages 239-244 in: Ecology of Leaf Surface Micro-organisms. T. F. Preece and C. H. Dickinson, eds. Academic Press, London.

17. Gregory, P. H. 1973. Microbiology of the Atmosphere. N. Polunin, ed. Leonard Hill Books, Aylesbury. p. 377.

18. Hartman, G. L., Hines, R. A., Faulkner, C. D., Lynch, T. N., and Pataky, N. 2007. Late season occurrence of soybean rust caused by Phakopsora pachyrhizi on soybean in Illinois. Plant Dis. 91:466.

19. Huff, F. A. 1970. Spatial distribution of rainfall rates. Water Resour. Res. 6:254-260

20. Huff, F. A. 1974. Statistics of precipitation. J. Recherches Atmos. 8:74-88.

21. Inglis, G. D., Ivie, T. J., Duke, G. M., and Goettel, M. S. 2000. Influence of rain on conidial formulation on persistence of Beauveria bassiana on potato leaves and Colorado potato beetle larvae. Bio. Control 18:55-64.

22. Inglis, G. D., Johnson, D. L., and Goettel, M. S. 1995. Effects of simulated rain on persistence of Beauveria bassiana conidia on leaves of alfalfa and wheat. Biocontrol Sci. Technol. 5:365-369.

23. Isard, S. A., Dufault, N. S., Miles, M. R., Hartman, G. L., Russo, J. M., De Wolf, E. D., and Morel, W. 2006. The effect of solar irradiance on the mortality of Phakopsora pachyrhizi urediniospores. Plant Dis. 90:941-945.

24. Isard, S. A., Russo, J. M., and Ariatti, A. 2007. The Integrated Aerobiology Modeling System applied to the spread of soybean rust into the Ohio River valley during September 2006. Aerobiologia 23:271-282.

25. Isard, S. A., Russo, J. M., and De Wolf, E. D. 2006. The establishment of a national Pest Information Platform for Extension and Education. Online. Plant Heath Progress DOI:10. 1094/PHP-2006-0915-01-RV.

26. Jurick, W. M., II, Narvaez, D. F., Brennan, M. M., Harmon, C. L., Marois, J. J., Wright, D. L., and Harmon, P. F. 2008. Winter survival of the soybean rust pathogen, Phakopsora pachyrhizi, in Florida. Plant Dis. 92:1551-1558.

27. Kemerait, R. C., Sconyers, L. E., Jost, P. H., and Mills, W. A. 2006. Evaluation of fungicides for control of Asian soybean rust in Attapulgus, Georgia, 2005. F\&N Tests 61:FC072.

28. Krupa, S., Bowersox, V., Claybrooke, R., Barnes, C. W., Szabo, L., Harlin, K., and Kurle, J. 2006. Introduction of Asian soybean rust urediniospores into the midwestern United States - A case study. Plant Dis. 90:1254-1259.

29. Levy, C. 2003. A field evaluation of eight fungicides in the control of soybean rust in Zimbabwe during 2002-03. Commercial Oilseeds Producer Association, Harare, Zimbabwe.

30. Li, X., Engelbrecht, C. J., Mueller, D. S., and Yang, X. B. 2008. First report of soybean rust caused by Phakopsora pachyrhizi in Iowa and its statewide occurrence. Plant Dis. 92:975.

31. Li, X., Yang, X. B., Mo, J., and Guo, T. 2009. Estimation of soybean rust uredospore terminal velocity, dry deposition, and the wet deposition associated with rainfall. Eur. J. Plant Pathol. 123:377-386.

32. Littell, R. C., Milliken, G. A., Stroup, W. W., Wolfinger, R. D., and Schabenberger, O. 2006. SAS for Mixed Models. 2nd ed. SAS Institute, Cary, NC.

33. Madden, L. V. 1992. Rainfall and the dispersal of fungal spores. Pages 39-79 in: Advances in Plant Pathology. Vol. 8. J. H. Andrews and J. Tommerup, eds. Academic Press, New York.
34. Madden, L. V., Wilson, L. L., Yang, X., and Ellis, M. A. 1992. Splash dispersal of Colletotrichum acutatum and Phytophthora cactorum by short-duration simulated rains. Plant Pathol. 41:427-436.

35. Madden, L. V., Yang, X., and Wilson, L. L. 1996. Effects of rain intensity on splash dispersal of Colletotrichum acutatum Phytopathology 86:864-874.

36. Marchetti, M. A., Urecker, F. A., and Bromfield, K. R. 1975. Uredial development of Phakopsora pachyrhizi in soybeans. Phytopathology 65:822-823.

37. Miles, M. R., Frederick, R. D., and Hartman, G. L. 2003. Soybean rust: Is the U.S. soybean crop at risk. APSnet Feature. Retrieved on September 9, 2007 from http://www.apsnet. org/online/feature/rust/.

38. Miles, M. R., Levy, C., Morel, W., Meuller, T., Steinlage, T., van Rij, N., Frederick, R. D., and Hartman, G. L. 2007. International fungicide efficacy trials for the management of soybean rust. Plant Dis. 91:1450-1458

39. Mueller, T. A., Miles, M. R., Hartman, G. L. O'Brien, G. K., Marois, J. J., and Wright, D. L. 2008. Evaluation of fungicide timing for the control of soybean rust in northwest Florida, 2006 Plant Disease Management Reports (online). Report 2:FC086. DOI:10.1094/PDMR02.

40. Narvaez, D. F., Jurick, W. M., II, Marois, J. J., and Wright, D. L. 2010. Effects of surface wetness periods on development of soybean rust under field conditions. Plant Dis. 94:258-264.

41. Ntahimpera, N., Wilson, L. L., Ellis, M. A., and Madden, L. V. 1999. Comparison of rain effects on splash dispersal of three Colletotrichum species infecting strawberry. Phytopathology 89:555-563.

42. Park, S., Chen, Z.-Y., Chanda, A. K., Schneider, R. W., and Hollier, C. A. 2008. Viability of Phakopsora pachyrhizi urediniospores under simulated southern Louisiana winter temperature conditions. Plant Dis. 92:1456-1462.

43. Pivonia, S., Yang, X. B., and Pan, Z. 2005. Assessment of epidemic potential of soybean rust in the United States. Plant Dis. 89:678-682.

44. Rossi, V., Giosue, S., and Bugiani, R. 2003. A model simulating deposition of Venturia inaequalis ascospores on apple trees. Bull. OEPP/EPPO 33:407-414

45. Rowell, J. B., and Romig, R. W. 1966. Detection of urediospores of wheat rusts in spring rains. Phytopathology 56:807-811.

46. Sikora, E. J., Delaney, D. P., Delaney, M. A., Lawrence, K. S., and Pegues, M. 2009. Evaluation of sequential fungicide spray programs for control of soybean rust. (online) Plant Health Progress DOI: 10.1094/PH-20090402-01-RS.

47. Szabo, L. J. 2007. Spore trapping: Technologies and results from 2007. Proc. 2007 Nat. Soybean Rust Sympos.

48. Twizeyimana, M., Ojiambo, P. S., Ikotun, T., Paul, C., Hartman, G. L., and Bandyopadhyay, R. 2007. Comparison of field, greenhouse, and detached-leaf evaluations of soybean germplasm for resistance to Phakopsora pachyrhizi. Plant Dis. 91:1161-1169.

49. Velez-Climent, M. C. 2008. Adhesion of Phakopsora pachyrhizi urediniospores to soybean leaves. M.S. thesis. Pennsylvania State University: University Park. p. 153

50. Wright, D. L., Rich, J. R., Marois, J. J., Sprenkel, R. K., and Ferrell, J. A. 2006. Soybean production in Florida. Florida Cooperative Extension Service, Institute of Food and Agricultural Sciences. Online. http://edis.ifas.ufl.edu/ AG185.

51. Yorinori, J. T., Paiva, W. M., Frederick, R. D., Costamilan, L. M., Bertagnolli, P. F., Hartman, G. L., Godoy, C. V., and Nunes, J., Jr. 2005 . Epidemics of soybean rust (Phakopsora pachyrhizi) in Brazil and Paraguay from 2001 to 2003. Plant Dis. 89:675-677. 